\title{
Novel acyclic nucleoside analogues as inhibitors of HIV-1 RT
}

\author{
Anuradha Singh, Madhu Yadav, Dipti Yadav, Garima Kumari, Ramendra K Singh* \\ From First International Science Symposium on HIV and Infectious Diseases (HIV SCIENCE 2012) \\ Chennai, India. 20-22 January 2012
}

\section{Background}

Nucleoside reverse transcriptase inhibitors (NRTIs) were the first drugs introduced for treatment of human immunodeficiency virus-1 (HIV-1) infection. These NRTIs may be cyclic or acyclic analogs of natural nucleosides. Both these analogs interact at active site on HIV-RT and compete with indigenous nucleosides/ nucleotides, and thus, divert enzyme activity in manmade direction. All NRTIs follow three phosphorylation steps that convert the parent compound successively to 5'-triphosphate. These 5'-triphosphates act as alternate substrate for HIV-RT, and lead to chain termination when incorporated into the DNA chain as they don't provide the 3'-OH function.

\section{Method}

Development of acyclic allylic nucleoside analogs, which act as NRTIs against HIV, involves both the computational and synthetic methods. Designing is done keeping the Lipinski's Rule of Five in focus and SAR studies were performed using DS 3.0 software. The ADMET descriptor and TOPKAT protocol available in DS 3.0 were used to predict these properties. The Lipinski's Rule of Five was also used to determine the biological activity or druglikeness of the designed inhibitors.

\section{Result}

All acyclouracil analogues formed 3-10 bonds with amino acids constituting the dNTP site on HIV-RT. The amino acids that interact with these molecules are Gln44, Lys46, Lys65, Arg72, Asp110, Asp113, Gln151, Asp185, Pro217, His221, Lys223 through H-bonding and $\pi-\pi$ interaction.

\footnotetext{
* Correspondence: singhramk@rediffmail.com

Nucleic Acids Research Laboratory, Department of Chemistry, University of Allahabad, Allahabad (UP)-211002, India
}

(c) 2012 Singh et al; licensee BioMed Central Ltd. This is an Open Access article distributed under the terms of the Creative Commons Attribution License (http://creativecommons.org/licenses/by/2.0), which permits unrestricted use, distribution, and reproduction in any medium, provided the original work is properly cited. and take full advantage of:

- Convenient online submission

- Thorough peer review

- No space constraints or color figure charges

- Immediate publication on acceptance

- Inclusion in PubMed, CAS, Scopus and Google Scholar

- Research which is freely available for redistribution Submit your manuscript at
www.biomedcentral.com/submit C BioMed Central 